\title{
The Role and Position of the Soldier in the New Democratic Societies the Case of Kosovo
}

\author{
Xhavit Sadrijaj \\ Ph. D. candidate at the Institute of European Studies, University of Tirana \\ xhavit.sadrijaj@rks-gov.net
}

Doi:10.5901/ajis.2015.v4n1s2p207

Abstract

The world before has never changed in such a short time like it did in the ending of the last millenium and beginning of the new one. Especially important in this period of time was the fall of the USSR and Yugoslavia from which compounds new countries were established. Even The Republic of Kosovo is a result of this process, although its expensive cost of independence. The resurrection and the construction of the new state, was and continues to an oscillation in the sound of the state building. Within those sounds is also the building of Kosovo Armed Forces of the Republic of Kosovo. The basic basis of the army as a social institution are soldiers and key principles like: unity, strong rules and disciplines. The commitment of the citizen in the army automatically changes its position and role to society itself. The soldier's role as an inseparable part of society in the Republic of Kosovo was to be a liberator, be reconstructive, and finally defending the country while preparing himself for the mission of peace and security guards in its own state and also regional and global stability.

Keywords: Role, soldier, society, security, principles

\section{Incoming}

The late swung and shake of the milenium we left behind, through difficult processes, to enter a new world order, beside others brought also new countries out. Offspring of this swung is also the newest country in the world, now recognized from over 100 sovereign status known on the globe map, is the Republic of Kosovo.

Kosovo's journey through this process was quite expensive. Serbia knew clearly that the process towards a new order, can not be stopped, and tried to take as much territory and extend its state borders to the detrimentof former neighbors until that time, causing wars with tragic proportions where hundred of thousand people lost their lives.

In the former Socialist Federal Republic of Yugoslavia, Kosovo's status has been almost equivalent to that of republics under its Constitution, year 1974. This situation changed in mid-1989, under the leadership of Milosevic, when Serbia announced a new constitution which illegally abolished Kosovo's status as an autonomous province in Yugoslavia. ${ }^{1}$ The unprecedented violation of basic human rights of Kosovo Albanians under the constitution (which lasted for a decade row), forced the leader of the majority in Kosovo Albanians, to counter in 1991 by organizing a referendum, which declared Kosovo independent.

After a decade of systematic violence exerted against the Albanian majority from the police and military machinery of Serbia, Kosovo created the Kosovo Liberation Army (KLA) as a popular mobilization for the liberation of Kosovo. The Serbian strategy was that by implementing the secret plan "Horseshoe (al-Patkoi)" drafted earlier by Milosevic's generals, to begin emptying the territory from indigenous Albanians and settle a Serbian territory in it. ${ }^{2}$ The purpose of Serbian politics was impeding the return of the population in their lands. ${ }^{3}$

Republic of Kosovo had to pay dearly for the liberation from a regime with such cravings.

Over ten thousand Albanians were killed, (of which approximately three thousand are still considered missing), nearly 800,000 Albanians were forced to flee their homes in Kosovo during this period and tens of thousands of homes were burned and destroyed. ${ }^{4}$ The extinction of the tendentious brutal cravings was accomplished with the birth of the Kosovo Liberation Army, which emerged from among the people and said enough to the fascist regime and later on also

\footnotetext{
1 https://history.state.gov/milestones/1989-1992/breakup-yugoslavia

2 Stoessinger, John G., Përse Kombet Shkojnë në Luftë, Instituti i Studimeve Ndërkombëtare, Tiranë, 2007, fq. 154

${ }^{3}$ Malcolm, Noel, Kosova një histori e shkurtër, Koha \& Shtëpia e librit Prishtinë, Tiranë 2001, fq.xxx

${ }^{4}$ http://www.mfa-ks.net/?page=1,121 
the international military intervention after the failure of numerous peaceful attempts, with a three-month campaign from air forces-NATO North Atlantic alliance, that forced Serbia to withdraw from Kosovo.

\section{The Role and Position of the Kosovar Soldier, in the Yugoslav Society}

Yugoslavia was a federal state with a socialist system of governance. Since the establishment the state was under the full authority of the Communist Party of Yugoslavia, later on came the League of Communists of Yugoslavia which was led from 1939-1980 by Josip Broz Tito, who took all important state decisions. ${ }^{5}$ Its army, which was initially named the Yugoslav Army and in 1953 the Yugoslav People's Army, was under strict control of the party, and had a special position in the political system, which came to light during the dissolution of the state. The Yugoslav People's Army proclaimed to be an organization that was equally represented by all the people of Yugoslavia, but in reality it was dominated by the Serbian cadres. The representation of Albanians as military cadres or military officers, was smaller than proportional ${ }^{6}$. It was also found in literature data that it was consisted up to $80 \%$ of Serbian staff. ${ }^{7}$ Servicing in the Yugoslav People's Army was mandatory ${ }^{8}$. The Kosovar soldier especially he who had an Albanian nationallity, who was obliged and forced to serve the military service in the former Yugoslav People's Army, has always been, and especially since 1991, in a very unfavorable position than the soldiers who belonged to other nations who also served there. He was in a very unfair position, that sometimes was even life threatening. Kosovar-Albanian soldier always after he recruted, hie was appointed to service far from his family, in units with severe specialities (infantry, hill and mountain units, heavy artillery . . ) in the barracks with the most weak conditions and an inappropriate staff. Frequently he had to perform all the physical works that were required, within and outside the barracks where he served. These barracks in a military jargon were called "the punishing" barracks. It happened very rarely that a Kosovo Albanian draftee would be assigned to an better specialty and advanced such as communications, aviation, military medicine etc. The Albanian soldier was always followed by various mechanisms installed by the intelligence services and commands in the barracks where he was serving. He was labeled as inappropriate, dangerous and he should always be kept under surveillance and control. He was constantly being questioned by the intelligence organs and also tortured in their offices during nights. It was expected from the Albanian soldiers to convey and talk to each other and then to provide informations to these services (to spy on each other). All those who refused to do such a thing, were abused in various ways, transferred into other units, imprisoned, and many were also returned to their families in coffins from the service. And in that case the families were told that their son commited suicide. ${ }^{9}$

Many of these can be read in books: Shaban Braha "The great Serb genocide and the Albanian resistance (18441990)", Publishing House "Lumi-T", Gjakova, 1991; and original documents Mr. Baliu Begzat, which are stored in the archive of Kosovo.

Unfortunately these painful cases are still unclear today.

\section{The Role and Position of Kosovan Soldier in the Liberation of the Country, Aiming for a State and a Liberal Democracy}

"I refrain to the experience that war does not solve anything. However, sometimes it is necessary and nothing else remains (. . . . $)^{10}$ Günter Grass

Kosovo Liberation Army was established in extraordinairy circumstances, from the boys and girls of Kosovo that were forced to become soldiers to protect home and family from a total destruction which was systematically practiced by a tremendous brutal and repressive power of a regime of a "weekend" federation, that was announced by the remains of the former Yugoslavia in 1992 ${ }^{11}$. This federation created from Serbia and Montenegro lived until 2006 and was named the third Yugoslavia. ${ }^{12}$ Kosovo was not included in the framework of the Conference of Dayton. ${ }^{13}$ Asked why Kosovo

\footnotetext{
${ }^{5}$ Matković, Hrvoje - Povijest Jugoslavije, Naklada Pavicic, Zagreb 1980, f 340

6 Ibid pg. 356

${ }^{7}$ Katana, Halil Tri Dimensionet e Luftës Çlirimtare te Kosovës, Argenta-LMG, 2002, Tirane f.12

${ }^{8}$ Grup autorësh, Mbrojtja e Jugosllavisë Socialiste, Narodna Armija, Beodrag 1971, f.195

9 Halilbegović, Nihad, "Mama, moram im glavu dati..." izdavač Halkomex, Sarajevo 2002, fq. 355

10 Focus Magazin, nr.27(1999)

11 Karastojanov, Stefan, Kosova nje analizë gjeopolitike, SEREMBE, Shkup 2007 fq. 195

12 Ibid
} 
was not invited to this conference, senior US representative Mr. Rossi responded that "in the conference are invited those who have fought, Kosovo did not fight therefor it was not invited". ${ }^{14}$ In that time and circumstances, the international community was not located and harmonized, nor was there any concrete plans regarding the situations that will arise after the conference in South Eastern Europe. All European Union countries knew that Serbia under Milosevic's leadership was a source of grave abuses of human rights in Kosovo, also knew that the conflict was very destabilizing for Europe, however, failed to take a collective decision to deploy a decisive military force to remove Slobodan Milosevic from his power, heading so to the heart of the problem. ${ }^{15}$

The slow treatment of the situation encuraged Milosevic to begin realizing his plans with the police and military to expand their territory through harsh attacks on all forms and all possible tools, through the villages of Kosovo, beating, torturing, persecuting, killing and slaughtering in the most cruel forms the citizens of those towns, also eliminating entire families, with the aim of introducing the horror to the Kosovo population, causing the indigenous people to leave their lands.

Yugoslav Army forces attacked with artillery shells the house of Adem Jashari, in Prekaz. At the end of the day the house was turned into a stones pile, dead bodies and blood. ${ }^{16}$

Prekaz massacre was the culmination of all patience, people were mobilized and came out in defense of the homeland. Thus, the Kosovo citizen from the position of a man who should have lived free in his society, thinking about his future and the family, was forced just because of the "Yugoslav" society in which he lived at the time, to leave his family, work, education, the environment and become a soldier, and a fighter against that society, because he had to protect the family from extinction and create a safe environment to live in a new socielty, in a new country with democratic values that were completely the opposite from those that belonged to the last society.

The role and position of citizen soldier, during the liberation war was appalling but also a strong base of the freedom and independence of Kosovo that the society enjoys today, and which came as a result of the decisions of the soldier at a difficult time putting their lives at the doors of death for freedom.

"Everything in war is very simple but the simplest thing is difficult ..."

-Carl von Clausewitz

\section{The Role and Position of the Soldier in the Reconstruction of the Country}

Kosovo was liberated thanks to the just war of the Kosovo Liberation Army and the great assistance of the North-Atlantic Alliance. Besides the human victims, the war left behind also colossal devastation on materials in the territory of Kosovo including all sectors of life (housing, road infrastructure, energy, water, schools, clinics). Most people were outside the country, expelled and fled from the horror that the country went through . ${ }^{17}$

The role of the liberators was coming to an end, and so was also the Kosovo Liberaton Army mission.

The future of the position and role of the soldier after the war in Kosovo was undefined. The citizen soldier was now in front of a new challenge, interwoven into its junction for further guidance. As a fighter for freedom, who contributed to the liberation of the country he saw himself a part of the military or any other institution that would come from the transformation of the KLA, which came from the international agreements. ${ }^{18}$

The international community through the implaned administration with the Resolution 1244 of the UN had its own plans in Kosovo that did not fairly fit with the prediction of the Kosovar soldier.

Today's soldier, yesterday's citizen, was located in a very unclear tomorrow. About $70 \%$ of liberation soldiers had no place in the troop which was established through laborious negotiations of temporary leaders of the national and international representatives. They remained at the mercy of developments.

13 The General Framework Agreement for Peace in Bosnia and Herzegovina, also known as the Dayton Agreement, Dayton Accords, Paris Protocol or Dayton-Paris Agreement, is the peace agreement reached at Wright-Patterson Air Force Base near Dayton, Ohio, United States, in November 1995, and formally signed in Paris on 14 December 1995. These accords put an end to the 3 1/2-yearlong Bosnian War, one of the armed conflicts in former Yugoslavia.

14 Islami, Bedri, E fshehta e hapur për Kosovën, Epoka e Re 2001 Prishtine, f. 57

${ }^{15}$ Fukuyama, Francis Ndërtimi i shtetit, Qeverisja dhe Rendi Botëror ne Shekullin e Njëzetë e Një, AllS, Tiranë 2008, f. 171

${ }^{16}$ Karastojanov, Stefan, Kosova një analizë gjeopolitike, SEREMBE, Shkup 2007 fq. 206

17 Karastojanov, Stefan, Kosova një analizë gjeopolitike, SEREMBE, Shkup 2007 fq. 206

18 Këshilli i Sigurimit i KB-ve, Rezoluta 1244 (1999) 4 KFOR, dhe

Marrëveshja për demilitarizimin e UÇK-së, (1999) 
As shown in the IOM report, the interest of former KLA members to be part of the Kosovo Protection Corps was extremely large. ${ }^{19}$ The small number of freedom soldiers who remained in the created troop called the Kosovo Protection Corps $^{20}$ based on its mission were called members of the troop and not soldiers.

Although there was no military mission, the Corps was organized in a very functional structure, very similar to military structures, it was an uniformed corps, which had rules and principles, command hierarchy from the top until down and soon achieved to be the most respected institution for Kosovo's new society but also for the international presence in Kosovo.

Soldiers of yesterday now members of the Kosovo Protection Corps, changed their role in the new society. ${ }^{21}$ They became from liberators to the biggest helpers of the people in rebuilding the country, clearing the territory of mines and other explosive tools and rised awareness on the people of their danger, by offering medical services even in remote villages and protecting all people of Kosovo regardless of ethnicity, color, religion, from all the disasters that could occur.

Yesterday's Liberation Army soldiers, members of the Protection Corps now, proved that they fought for an all popular freedom and a multi-ethnic democratic society. They were also the first institution which in the framework of standards to UN Special Representative for Kosovo, filled the standard number VIII that was dedicated to this troop. ${ }^{22}$ Kosovo Protection Corps are the first institution which integrated all national minorities in Kosovo in its structure.

During the nine years of existence of this troop, also by thanking the right understanding of the mission by its members, has built houses, roads, bridges, schools, clinics, and firefighting objects.

The members of this troop have cleared tens of thousands of square kilometres of the territory of Kosovo from mines and unexploded tools. The troop has received numerous gratitudes and praises for its work and commitment from the international and local officials, and it also has been positively valued on the report of the Special Envoy of the UN Security Council's. ${ }^{23}$ This troupe worked closely with the international factor in Kosovo, from which it was guided, supervised and financed, especially with KFOR.

Members of the force were trained and specialized home and abroad, and sometime later became the core of the institution that emerged later, called Kosovo Security Force.

Kosovo Protection Corps were disbanded on 20 January 2009.

\section{The Role and Position of the Soldier in the Independent State}

Nearly a decade after the war, the country had progressed in the formation of conditions for self-government. In cooperation with the international community, and its strategic friends, on 17. 02.2008 Kosovo declared its independence.

Kosovo's declaration of independence marked a historic step in the life of this country, and the beginning of the way of construction and consolidation of the democracy that was also desired by all Kosovars.

This important act coincided with the proposal for a new security architecture in Kosovo based on the plan of UN Special Envoy for Kosovo's Status known as the Ahtisaari Plan. ${ }^{24}$

Under this plan on 20th January 2009 the Kosovo Protection Corps were disbanded, and at midnight of the same day the mandate is submitted to the newly formed Kosovo Security Force. ${ }^{25}$

This plan, besides others said: ". . . In Kosovo should be a new Security Force (KSF) built, which must be professional and multi-ethnic, lightly armed and that has no heavy weapons, . . . with no more than 2,500 active and 800 reserve members. "

Extinction of the Kosovo Protection Corps, KPC and building of the Kosovo Security Force, KSF, were a parallel

${ }^{19}$ IOM, Kosovo KPC, 2000 Deri në 20.000 persona kanë aplikuar për pozita në TMK. Prej tyre 17.000 kanë qenë luftëtarë të UÇK-së prej 27.000 sa kanë qenë të evidentuar gjithsej.

20 Trupat e Mbrojtjes se Kosovës janë institucion i themeluar ne bazë te Rregullores se UNMIK-ut nr. 1999/8, të datës 20 shtator 1999 e shikuar me datën 15. 02. 2015, ne linkun: http://www.unmikonline.org/regulations/unmikgazette/03albanian/A1999regs/RA1999_08.htm

${ }^{21}$ Rregullore e UNMIK-ut nr. 1999/8, neni 1, pika 1.1, detyrat dhe përgjegjësitë e pjesëtarëve te TMK-së.

22 Rregullore e UNMIK-ut nr. 1999/8, neni 1, pika 1.1, detyrat dhe përgjegjësitë e pjesëtarëve te TMK-së.

${ }^{23}$ Raporti i datës 07. 10. 2005 i z. Kai Eide (Norwegji), i dërguari i posaçëm i përfaqësuesit te Këshillit te Sigurimit te OKB-së për rishikimin e situatës ne Kosovë, Serbi dhe Mal te Zi, fq.5 pika 25. Shikuar me datën 16. 02. 2015 ne linkun: http://www.securitycouncil report.org/atf/cf/\%7B65BFCF9B-6D27-4E9C-8CD3-CF6E4FF96FF9\%7D/kos\%20S2004\%20932.pdf

24 http://www.unosek.org/unosek/en/statusproposal.html The Comprehensive proposal for Kosovo Status Settlement

${ }^{25}$ http://www.unosek.org/unosek/en/statusproposal.html The Comprehensive proposal for Kosovo Status Settlement pika II.9 Security 
process and also the next big challenge for the soldiers of freedom. It was a painful process.

In the Kosovo Security Force passed 50\%, or about 1,400 former members of the KPC. ${ }^{26}$ This caused dissatisfaction to the large remaining part outside the structures of the KSF which was firstly manifested with protests in front of the KSF objects beginning with the Ministry of the KSF. ${ }^{27}$

Soldiers who clashed in the late challenges of the last and first decade of the new century, soldiers of liberation, and after that, an important part of building the country, felt deeply disappointed and offended. Thanks to their maturity, protests were relatively held under control. Looking at the created situation, the international representation which was directly involved in the creation of the Ministry of the Kosovo Security Force and also the Kosovo Security Force, provided a small opportunity for members who really wanted to be part of the KSF, to subject retesting and to be sent in the initial training, training which the members who were already part of the KSF had carried out too.

The members that were chosen were extremely successful in the initial training. They did their best to prove that they deserve to be part of the new Force. But because the positions in Kosovo Security Force foreseen to be completed with former members of the Kosovo Protection Corps in structure, were mostly covered, to members who completed training were offered low ranks positions, only a few of them were officer ranks the others were beginner NCOs and soldiers.

Based on the fact that many of them carried the highest officer rank in the Kosovo Protection Corps, they did not agree with the ranks and positions that were offered to them so they were even more disappointed and they initially fled, only a part of them suppressed by pride and also social situations, accepted to serve in these ranks.

Members of the former KPC which were transferred to the Kosovo Security Force, although really felt the absence of their yesterday's collegues, saw right before their mission and started working to build and strengthen the force. The construction began almost from zero because it was not wanted to have a continuity of KPC. Timely the KSF complied the standards which the international community has set before them, the initial operational kapacities and full operational kapacities. ${ }^{28} \mathrm{KSF}$ proved with its soldiers true operational capabilities in all trainings within and outside the country. Members of the force have reached great results in different centers wherever they were sent, for military training, education and specialization. KSF soldiers continued clearing the territory of Kosovo by mines and unexploded tools, offered assistance in all areas where it was required. KSF soldiers even intervened in very difficult conditions in places where and when no one could. Under 15 feet of snow after the avalanche disaster, they achieved to rescue a 5 year old girl in the village Restelicë in southern Kosovo. ${ }^{29}$

KSF soldiers intervened outside the borders of the country too, helping the people of the Republic of Albania in natural disasters-floods several times ${ }^{30}$ and also in clearing the territory after the fatal explosion of the explosions and missiles in Gërdec village. KSF soldiers kept their role and position in the force by serving with maximum dedication to the Kosovo people and the local and regional security. KSF was now a factor of stability in the region.

KSF completed its mission successfully. Now it is a highly respected force in Kosovo and is internationally pending for the status and new mission. After reviewing the security sector, this force will be transformed into the Armed Forces of the Kosovo-KAF.

Its name and its mission will change after the complete change of Legislation starting from the Constitution of the country and also after the Parliament approves the change of the amendments of the Constitution and the draft for the establishment of the Armed Forces of Kosovo.

\section{Conclusion}

Nevertheless, one can emphasize that with the end of the war in Kosovo, the new world order began to take shape. New state that emerged through this process came across huge difficulties and problems. However, in my personal view, the best example of this is Kosovo, which has paid the biggest price of being released from the oppression of the last century. Kosovo is a unique case of the clashes during last centuries - constantly fighting for equal rights.

At the same time, Kosovo is an example of initiation and the quest for freedom and human rights in Europe, forced

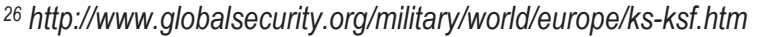

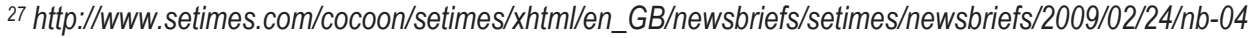

${ }^{28} \mathrm{http}$ ://www.setimes.com/cocoon/setimes/xhtml/en_GB/newsbriefs/setimes/newsbriefs/2009/02/24/nb-04

29 http://koha.net/arkiva/?page=1,13,87716

30 http://politiko.net/fsk-ndihmon-shqiperine/ shikuar se fundi 14. 02. 2015
} 
to live in a non-native state, enduring the violence and injustice coming from that state, 50 years of communism, two decades of apartheid, as well as two years of unequal and unjust war.

Kosovo is currently in the process of establishment of its own army forces (Kosovo Armed Forces).

As stated above, I did my best to present these tremendously important processes, based on the following literature and resources, hence also on my personal experience as an officer in the former Yugoslav People's Army, and as an officer in my homeland. The building of the Kosovar Army was difficult, filled with brimming laborious challenges. The soldier was the main weight-carrier of its journey. Therefore, the respect belongs to the Kosovar soldier.

To serve the homeland in all situations as a soldier is a great honor and privilege, it is also a holistic help that is given to the society in which he lives.

Being a soldier means to be more than ordinary citizen says Huntington, who advises that behind being a soldier, defender of the country, is also a heavy responsibility.

The greatest service they can do is to remain faithful to themselves, to serve quietly and couragesly in a military way. If they give up the military spirit, they destroy themselves in the first place and also their nation in the end. ${ }^{31}$

\title{
7. Acronyms
}

\author{
KLA- Kosovo Liberation Army \\ KPC- Kosovo Protection Corps \\ KSF- Kosovo Security Force \\ KAF- Kosovo Armed Forces \\ IOM- International Organization for Migration \\ KFOR- Kosovo Force of NATO
}

\section{References}

Stoessinger, John G. , Why Nations Go to War, Institute of International Studies, Tirana, 2007

Malcolm, Noel, Kosovo a short story, "Koha \& Shtepia e librit Pristine", Tirana 2001

Matkovic, Hrvoje - History of Yugoslavia, Circulation Pavicic, Zagreb 1980

Katana, Halil three dimensions of the Kosovo Liberation War, Argenta-LMG, 2002, Tirana

Group of authors, Protection of Socialist Yugoslavia, Narodna Armia, Beodrag 1971

Halilbegović, Nihad, "Mom, I have to give them a head . . . " publisher Halkomex, Sarajevo 2002

Karastojanov, Stefan, Kosovo a geopolitical analysis, Seremb, Skopje 2007

Islam, Bedri, the open secret for Kosovo, New Age 2001 Pristina

Fukuyama, Francis State Building, Governance and World Order in the twenty-first century, AllS, Tirana 2008

Huntington, Samuel P. , The Soldier and the State, the Theory and Politics of Civil-Military Relations, The Belknap Press of Harvard University Press, renewed in 1985, FQ 466

\section{Electronic Resources}

https: //history. state. gov/milestones/1989-1992/breakup-yugoslavia

http: //www. mfa-ks. net/?page=1,121

http: //www. unmikonline. org/regulations/unmikgazette/03albanian/A1999regs/RA1999_08. htm

http: //www. securitycouncilreport. org/atf/cf/\%7B65BFCF9B-6D27-4E9C-8CD3-CF6E4FFF96FF9\%7D/Kos\%20Standards. pdf

http: //migration. ucdavis. edu/mn/more. php?id=1853_0_4_0

http: //www. securitycouncilreport. org/atf/cf/\%7B65BFC-F-7B-6D27-4E9C-8CD3-CF6E4FF96FF9\%7D/kos\%20S2004\%20932. pdf

http: //www. unosek. org/unosek/en/statusproposal. html The Comprehensive proposal for Kosovo Status Settlement

http: //www. unosek. org/unosek/en/statusproposal. html The Comprehensive proposal for Kosovo Status Settlement pika II. 9 Security

http: //www. unosek. org/unosek/en/statusproposal. html

http: //www. globalsecurity. org/military/world/europe/ks-ksf. htm

http: //www. setimes. com/cocoon/setimes/xhtml/en_GB/newsbriefs/setimes/newsbriefs/2009/02/24/nb-04

http: //www. globalsecurity. org/military///world/europe/ks-ksf-history. htm

http: //koha. net/arkiva/?page=1,13,87716

${ }^{31}$ Huntigton, Samuel $P$, The Soldier and the State, the Theory and Politics of Civil-Military Relations, The Belknap Press of Harvard University Press, renewed 1985, fq 466 
http: //politiko. net/fsk-ndihmon-shqiperine/ shikuar se fundi 14. 02. 2015

\section{Documents}

Focus Magazin, nr. 27 (1999)

The General Framework Agreement for Peace in Bosnia and Herzegovina, also known as the Dayton Agreement, Dayton Accords, Paris Protocol or Dayton-Paris Agreement, is the peace agreement reached at Wright-Patterson Air Force Base near Dayton, Ohio, United States, in November 1995, and formally signed in Paris on 14 December 1995. These accords put an end to the $31 / 2^{-}$ year-long Bosnian War, one of the armed conflicts in former Yugoslavia.

Security Council UN Resolution 1244 (1999) 4 KFOR, and the Agreement for the demilitarization of the KLA, (1999)

IOM, Kosovo CPC, 2000 to 20,000 people have applied for positions in the KPC. Of these 17,000 were KLA fighters of 27,000 were recorded as total.

UNMIK Regulation no. 1999/8, Article 1, paragraph 1. 1, the duties and responsibilities of the members of the KPC.

UNMIK / PISG January, 2004, the Standards for Kosovo, Presented Pristina, 10 January 2003 page, 15, seen 16. 02.2015

Report dated 07. 10. 2005 Mr. Kai Eide (Norwegji), special envoy of the representative of the UN Security Council for a review of the situation in Kosovo, Serbia and Montenegro

DCAF, Democratic Control of Armed Forces, 2008

IOM, Kosovo KPC, Prishtinë, 2000

KCSS, establishment, operability and democratic functioning of the KSF, Pristina, $2008 \mathrm{KFOR}$, the Agreement for the demilitarization of the KLA, Pristina, 1999

United Nations, 1244 Resolution, New York, 1999 NATO

Military Technical Agreement in Kumanovo, Kumanovo, 1999

UNDP, ISSR, Pristina, 2006 UNMIK, Standards for Kosovo, New York, 2003 
